\title{
Sediment Modeling of Kobadak River by Hecras
}

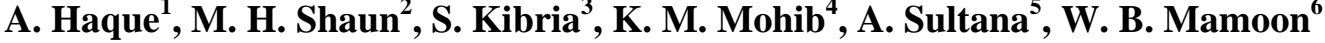 \\ ${ }^{1}$ Reseacrh Associate, Climate Modeling \& Simulation Lab, IWFM, Bangladesh University of Engineering \& Technology \\ akramul109183[at]gmail.com
}

${ }^{2}$ MSc. Student, Department of Water Resource Engineering, Bangladesh University of Engineering \& Technology, mmominulhossain[at]yahoo.com

${ }^{3}$ MSc. Student, Department of Water Resource Engineering, Bangladesh University of Engineering \& Technology, kibria.sayedul[at]gmail.com

${ }^{4}$ Graduate Student, Department of Water Resources Engineering Bangladesh University of Engineering \& Technology, kazimushfique23[at]gmail.com

${ }^{5}$ Lecturer, Department of Civil Engineering, Ahsanullah University of Science and Technology, Dhaka, Bangladesh, sultanaarifa90[at]gmail.com

${ }^{6}$ Reseacrh Associate, Climate Modeling \& Simulation Lab, IWFM, Bangladesh University of Engineering \& Technology, wasifbinmamoon[at]gmail.com.

\begin{abstract}
Kobadak River is one of the freshwater sources in the South-West region of Bangladesh. But due to cut off from Mathabangha River, Kobadak River has turned into a very narrow stream and hence it has been silted up over the years which cause water logging problems. This work focuses on the simulation of sediment transport for Kobadak River using a 1-D HEC-RAS model. This study reach is $120 \mathrm{~km}$ long which includes 27 cross-sections. Yang transport equation has been used as the diameter of sediment material ranges from 0.1 to $0.2 \mathrm{~mm}$. Equilibrium condition has been given as an upstream boundary condition. For sediment analysis, the grain size is very important where $d 50$ is $0.14 \mathrm{~mm}$. For calibration, manning's $n=0.021$ is used. This paper primarily focuses on identifying of erosion-deposition of the different cross-section for the year 2016 along Kobadak River where erosion-deposition is varied from 0.015 meters to 2 meters for different cross-sections. This study can be suitable for future policymaking regarding river restoration projects.
\end{abstract}

Keywords: Sediment Modeling, Yang Transport, Manning's n, Erosion-Deposition, Box Scheme, Hec-Ras

\section{Introduction}

River morphology can be explained by channel patterns and forms, and is affected by factors such as discharge, water surface slope, velocity, depth; channel width and river bed materials [1].An alluvial channel has a mobile bed, composed of non-cohesive granular materials. Such materials are unconsolidated silts, sands and gravels. The water and sediment discharges in natural alluvial streams, which have evolved over geologic times, are in equilibrium and produce no objectionable scour or deposition. However, if this delicate equilibrium or balance is disturbed by changing any of the properties like water and sediment discharges, channel geometry, slope, water and sediment properties etc., through natural or manmade factors, e.g., construction of weirs, barrages, dams, sudden change in sediment supply rate due to heavy erosion or landslide in river basin, narrowing of river for navigation, river dredging, etc. a process of achieving another state of equilibrium begins. The process is inevitably accompanied by aggradation and/or degradation along the river bed. In a word, as a dynamic system, alluvial river undergoes continuous changes always [2]. Knowledge of sedimentation phenomenon like erosion, sediment transport, sedimentation is of a great deal of importance. Reasonable estimate of the sediment transport rates in alluvial rivers is important in context of a number of water management issues. Sediment transport is a widely studied topic in which numerous researchers have built models based on various numerical schemes for predicting bed material transport rates in an alluvial river [3].Apart from Scale Models, Numerical or Mathematical models are useful instruments to study the problems of sedimentation, sediment transport and erosion. The numerical models like HEC-RAS, SMS SRH2D, and MIKE have been widely used by many researchers to simulate sedimentation and erosion scenarios [4, 5]. HECRAS is Box Scheme based open source numerical modeling software developed by United States Army Corps of Engineers. HEC-RAS has both the ability of one dimensional and two dimensional modeling of flow as well as sediment transport modeling capabilities [6].

Kobadak River originates from the Mathavanga River at Alamdanga, Chuadanga and falls into the Shibsa at Paikgacha, Khulna. The total length of the river is about 260 $\mathrm{km}$. This river has some navigational activities in Khulna district but mostly dried up in its upstream reaches [7]. The morphology of the Kobadak is governed by sedimentation process and the human induced influences. Overtimes the river has lost its drainage capacity due to reduced flow from upstream and large scale sedimentation. In natural state of flow the river had a great contribution in the socio economic factors like fisheries, navigation, agriculture, domestic uses etc. Due to cut off from the Mathavanga River, Kobadak has turned into a very narrow stream and hence it has been silted up over the years which cause water logging problems. It is

Volume 10 Issue 4, April 2021

www.ijsr.net

Licensed Under Creative Commons Attribution CC BY 


\section{International Journal of Science and Research (IJSR) \\ ISSN: 2319-7064 \\ SJIF (2019): 7.583}

necessary to manage the river in such a way that would. Be helpful to sustain ecosystem, maintain navigability, meet agricultural water demand and convey flood water [8]. This study mainly focuses on the simulation of sediment transport for Kobadak River using a 1-D HEC-RAS model.

\section{Study area}

For Research study, Kobadak River is selected for analysis due to the change of present condition specially flow and morphological changes over the year. The study area which is shown in figure-1 is located in South-East region of Bangladesh. The width of this river vary from 100-250 meter. The total length of Kobadak river is $150 \mathrm{~km}$. The study area starts from Jhikargacha station of Kobadak river. The river bifurcates into two at Paikgacha station at about $120 \mathrm{~km}$ of Jhikargacha station which is highlighted in [Fig.1]. The eastern reach is also known as Kobadak and the Western branch meets the Sibsa which flows through Sundarban.

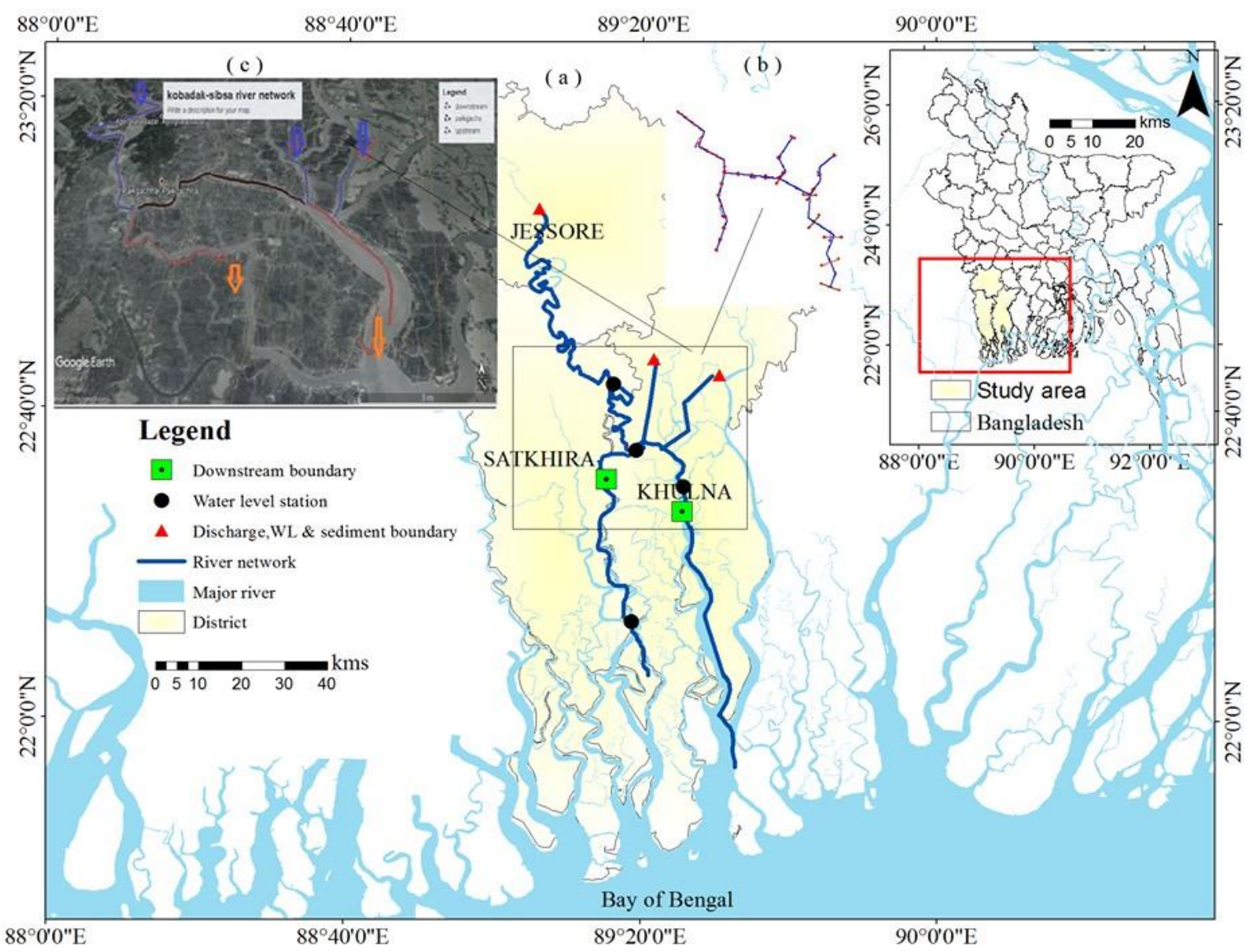

Figure 1: (a) Study area showing the river network, (b) Schematic diagram of river network in HEC-RAS, (c) Kobadak-Sibsa showing flowing outflow and inflow

\section{Methodology}

\subsection{Data collection}

For conducting the study cross sectional data of the river reach, stage and hydrograph data were necessary. The crosssectional data were collected from the Bangladesh Water Development Board (BWDB). Stage and flow hydrograph were also collected from Bangladesh Water Development Board (BWDB). Data related to sediment size was collected from the previous data records of Department of Water Resources Engineering, BUET. Flow hydrograph was derived from rating curve. The tidal stage hydrograph was generated based on the data collected from BWDB raw data and was prepared according to 6 hour interval. The bed gradation of the Kobabak River was classified according to Fig. 2. The maximum depth for possible erosion at any section was given 10 meter which is presented in Fig. 2..

\subsection{Sediment analysis and modeling}

For sediment modeling, we need to setup a hydrodynamic model. First, Schematic diagram was drawn in Geometric data editor in HEC-RAS. Then 27 cross section data were inserted in Geometric data editor. Flow hydrograph and stage hydrograph were given as upstream boundary and downstream boundary condition [Fig. 2]. The simulation time was for the year 2016. Then the model is calibrated with manning's ' $n$ ' for the month of July, 2016 and validated for the month July, 2015.For sediment modeling, sample size was given in the sediment data editor [Fig. 2] where $\mathrm{d} 50=0.14 \mathrm{~mm}$. After assigning max depth 10 meter, left bank and right bank station, yang equation was used as transport function [Fig. 2]. Yang transport equation was used as we only need to analyze erosion and sedimentation of river bed. Table. 1 is the input data range and Kobadak meets this data

\section{Volume 10 Issue 4, April 2021}




\section{International Journal of Science and Research (IJSR) \\ ISSN: 2319-7064 \\ SJIF (2019): 7.583}

range for Yang equation. Thomas sorting and Ruby fall for the year of 2016. velocity method was used. The equilibrium condition was used as the boundary condition for the sediment simulation

Flow hydrograph at Jhiargacha

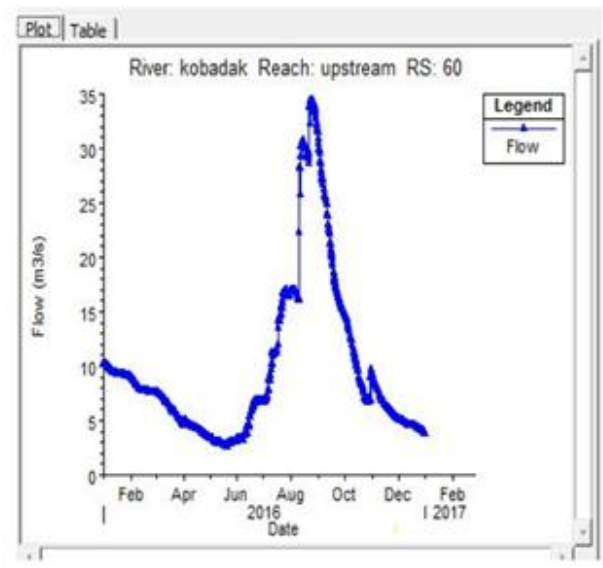

Stage hydrograph at boundary condition

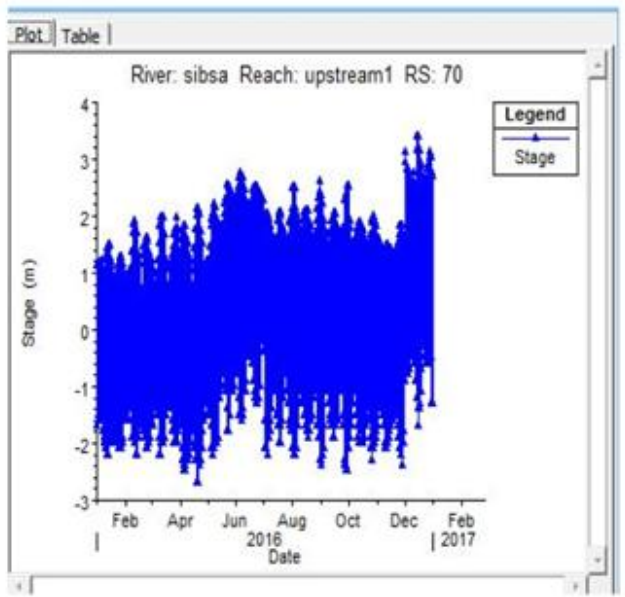

Sediment data

\begin{tabular}{|c|c|c|c|c|c|c|c|c|}
\hline River & Reach & RS & Invert & Max Depth & Min Elev & Left Sta & Right Sta & Bed Gradation \\
\hline coba-sba & pakgacha & 40 & -7.244 & 10 & & 139.2 & 556 & sample1 \\
\hline coba-sba & pakgacha & $39.989^{*}$ & -7.244 & 10 & & 139.21 & 556 & sample 1 \\
\hline coba-sba & pakgacha & $39.978^{*}$ & -7.244 & 10 & & 139.221 & 556 & sample 1 \\
\hline coba-sba & paikgacha & $39.967^{*}$ & -7.244 & 10 & & 139.231 & 556 & sample 1 \\
\hline caba-sba & paikgacha & $39.956^{*}$ & -7.244 & 10 & & 139.241 & 556 & sample1 \\
\hline coba-siba & pakgacha & $39.944^{*}$ & -7.244 & 10 & & 139.252 & 556 & sample1 \\
\hline coba-sba & pakgacha & $39.933^{*}$ & -7.244 & 10 & & 139.262 & 556 & sample1 \\
\hline coba-sba & pakgacha & $39.922^{*}$ & -7.244 & 10 & & 139.272 & 556 & sample 1 \\
\hline coba-siba & pakgacha & $39.911^{*}$ & -7.244 & 10 & & 139.283 & 556 & sample 1 \\
\hline coba-sba & paikgacha & $39.900^{*}$ & -7.244 & 10 & & 139.293 & 556 & sample 1 \\
\hline coba-siba & pakgacha & $39.889^{*}$ & -7.244 & 10 & & 139.303 & 556 & sample 1 \\
\hline caba-sba & pakgacha & $39.878^{*}$ & -7.244 & 10 & & 139.314 & 556 & sample1 \\
\hline caba-siba & pakgacha & $39.867^{*}$ & -7.244 & 10 & & 139.324 & 556 & sample1 \\
\hline cobasiba & pakgacha & $39.856^{*}$ & -7.244 & 10 & & 139.334 & 556 & sample1 \\
\hline coba-sba & pakgacha & $39.844^{*}$ & -7.244 & 10 & & 139.345 & 556 & sample 1 \\
\hline
\end{tabular}

Cross section plot of possible maximum erosion

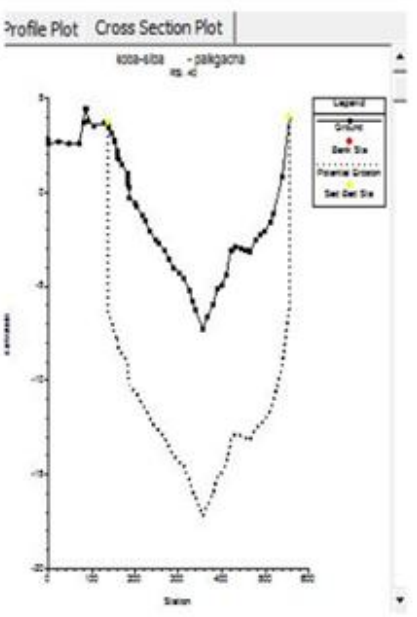

Bed gradation

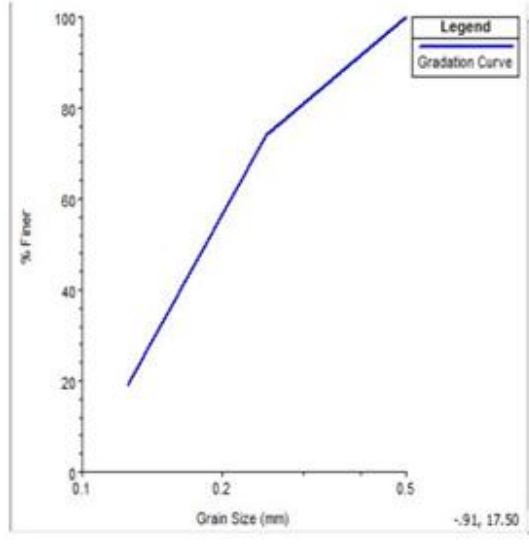

Figure 2: Hydro-dynamic and sediment data input in HEC-RAS

Table 1: Haghiabi [9], Input data range to calculate sediment load in HEC-RAS

\begin{tabular}{|c|c|c|c|c|c|c|c|c|}
\hline Function & $\mathrm{D}$ & $\mathrm{D}_{\mathrm{m}}$ & $\mathrm{S}$ & $\mathrm{V}$ & $\mathrm{D}$ & $\mathrm{S}$ & $\mathrm{W}$ & $\mathrm{T}$ \\
\hline Ackers-White (Flume) & $0.04-7$ & $\mathrm{NA}$ & $1-2.7$ & $0.07-7.1$ & $0.01-1.4$ & $0.00006-0.037$ & $0.23-4$ & $46-89$ \\
\hline Englund_Hansen(Flume) & NA & $0.19-0.93$ & NA & $0.65-6.34$ & $0.19-1.33$ & $0.000055-0.019$ & NA & $45-93$ \\
\hline Laursen(Field) & NA & $0.08-0.7$ & NA & $0.068-7.8$ & $0.67-54$ & $0.0000021-0.0018$ & $63-3640$ & $32-93$ \\
\hline Laursen(Flume) & NA & $0.011-29$ & NA & $0.7-9.4$ & $0.03-3.6$ & $0.00025-0.025$ & $0.25-6.6$ & $46-83$ \\
\hline Meyer-Peter-Muller(Flume) & $0.4-2.9$ & NA & $1.25-4$ & $1.2-9.4$ & $0.03-3.9$ & $0.0004-0.02$ & $0.5-6.6$ & NA \\
\hline Tofaletti(Field) & $0.062-4$ & $0.095-0.76$ & NA & $0.7-7.8$ & $0.07-56.7(\mathrm{R})$ & $0.000002-0.0011$ & $63-3640$ & $32-93$ \\
\hline Tofaletti(Flume) & $0.062-4$ & $0.45-0.91$ & NA & $0.7-6.3$ & $0.07-1.1(\mathrm{R})$ & $0.00014-0.019$ & $0.8-8$ & $40-93$ \\
\hline Yang(Field-Sand) & $0.15-1.7$ & NA & NA & $0.8-6.4$ & $0.04-50$ & $0.000043-0.028$ & $0.44-1750$ & $32-94$ \\
\hline Yang(Field-Gravel) & $2.5-7.0$ & NA & NA & $1.4-5.1$ & $0.08-0.72$ & $0.0012-0.029$ & $0.44-1750$ & $32-94$ \\
\hline
\end{tabular}

Here, $\mathrm{D}=$ overall particle diameter, $\mathrm{mm}$

$\mathrm{D}_{\mathrm{m}} \quad=$ Median particle diameter, $\mathrm{mm}$

$\mathrm{S} \quad=$ Sediment specific gravity

$\mathrm{V}=$ Average channel velocity

$\mathrm{D}=$ Channel Depth, $\mathrm{ft}$

$\mathrm{S}=$ Energy Gradient

$\mathrm{T} \quad=$ Water Temperature, Fahrenheit

$\mathrm{R}=$ Hydraulic Radius, NA = Data not available

\subsection{Model Calibration}

In literature review, it has been found that the accuracy of sediment simulation depends upon manning's $\mathrm{n}$ and sediment transport equation. According to data range shown in Fig. 3, the sediment parameters value of Kobadak are in acceptable

Volume 10 Issue 4, April 2021

www.ijsr.net

Licensed Under Creative Commons Attribution CC BY 


\section{International Journal of Science and Research (IJSR) \\ ISSN: 2319-7064 \\ SJIF (2019): 7.583}

range for yang transport equation. The hydrodynamic model is calibrated using the data of June, 2016 at Sutarkhali Forest Office station. Then this model is validated using the data of July, 2015 for the same station. Model simulated tidal range showed a satisfactory agreement with the observed values for Manning's roughness coefficient as 0.021 as R2 was found 0.96 for calibration and validation. Once the hydrodynamic model is calibrated and validated, the salinity model is performed.

\section{Results and Discussions}

To assess the morphological changes of the river, the model is simulated for the year of 2016. To stable the sediment model, the computational interval was reduced to 10 minutes. The changes in river bed for different cross sections are shown in [Fig. 3]. The invert changes of the cross section at paikgacha and at RMKBD 13 with time are also presented in the Fig. 3. The deposition of the River bed goes up to 4 meter at paikgacha and causes erosion about 2 meter [Fi.
3].The deposition at RMKBD 13 goes up to 2 meter from January, 2016 to mid Feb, 2016 and goes down at 1 meter in the month of June and again causes bed deposition up to 1.9 meter at end of December. In the cross section at RMKBD12 about 0.07 meter deposition occurs at the end of November, 2016. The River bed at cross-section at RMKBD-10.1 goes up and down from the month April to November, 2016. The net deposition occur at RMKBD 10.1 is about .007 meter in the end of 2016 year. It has been found that from profile plot of Kobadak upstream [Fig. 4], the river bed is in same elevation as January 01, 2016. But from the observation of time series invert change plot [Fig. $3]$, it is seen that the river bed locates at cross section at RMKBD 4 slightly increases its elevation which is $0.025 \mathrm{~m}$ at the end of month June, 2016. The actual situation of the river bed near the cross section at RMKBD 4 is also in stable condition. The cross sections at RMKBD 4 to RMKBD 12 remain in same bed elevation which is seen in [Fig. 4], profile plot of Kobadak upstream.

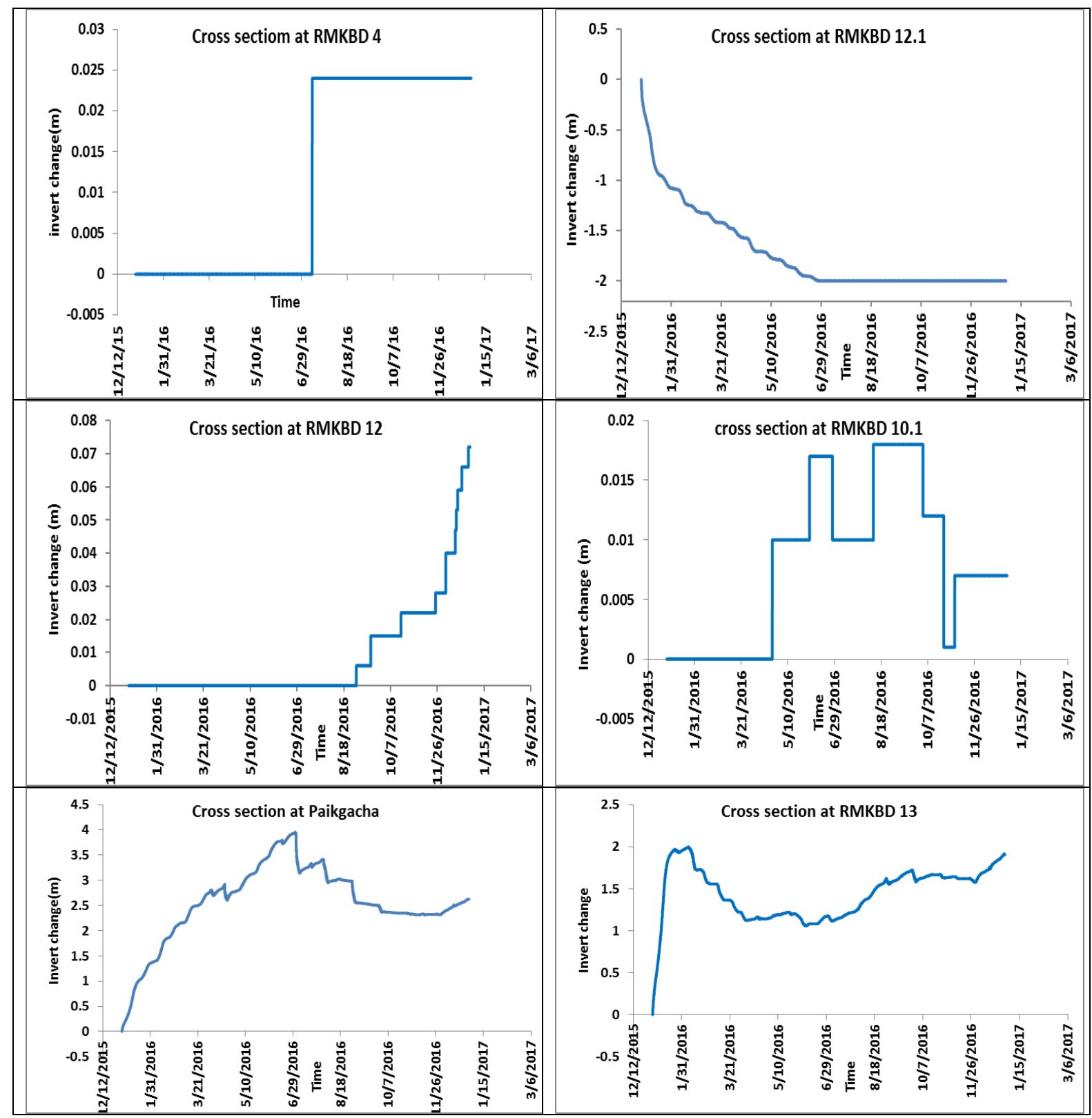

Figure 3: Time series invert change of different cross sections

Volume 10 Issue 4, April 2021

www.ijsr.net

Licensed Under Creative Commons Attribution CC BY 
Slightly upstream of Paikgacha, it has been found that there is erosion of river bed which is shown in [Fig. 4] (cross section at RMKBD 12.1). From [Fig. 4] (profile plot at upstream of Kobadak), the depth of river bed erosion goes up to 2 meter. This area is located upstream of Paikgacha confluence and there is located many bridges.

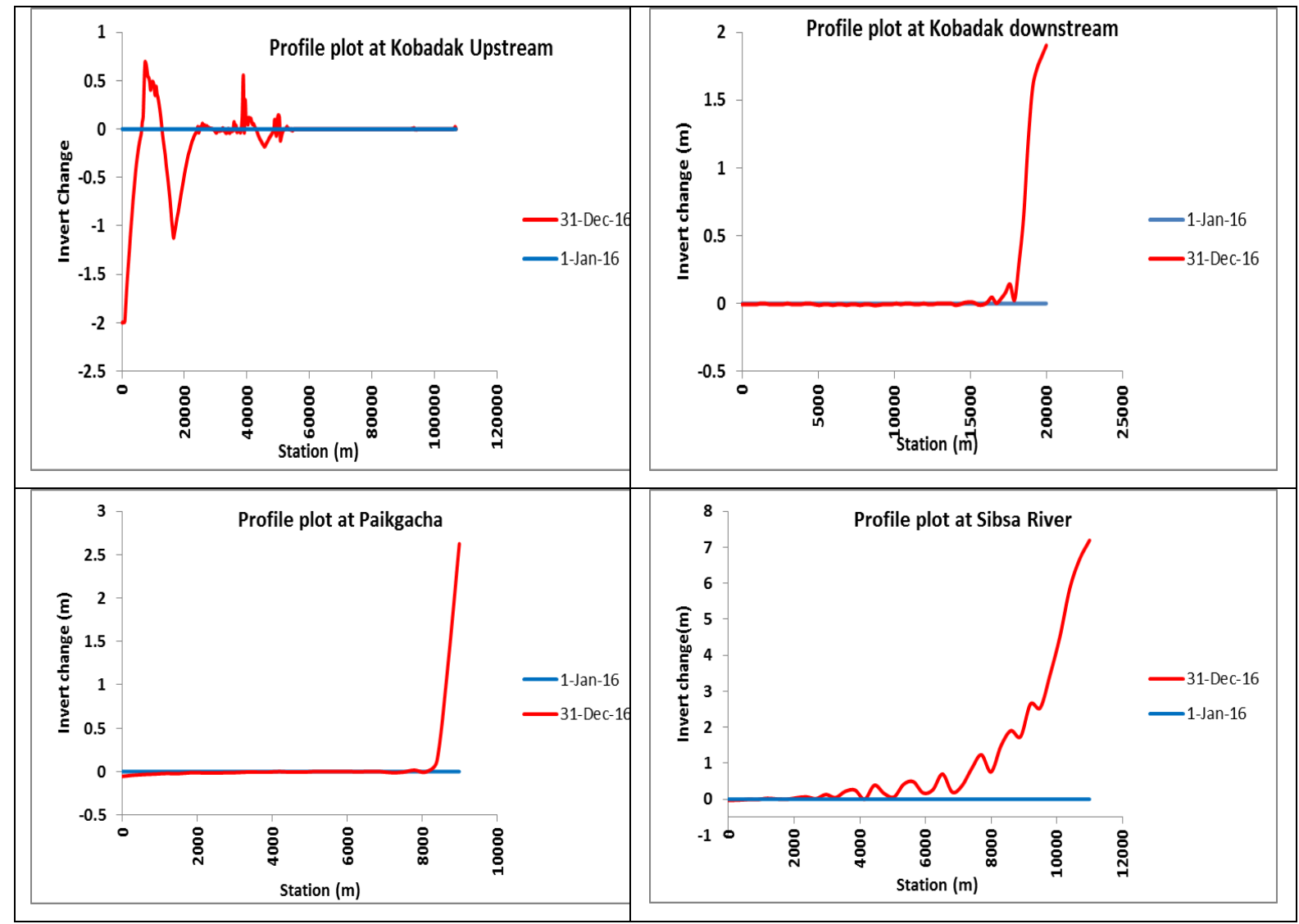

Figure 4: Profile of Invert Change along different river reach

From [Fig. 4], it is seen that downstream reach of Kobadak abruptly raises the bed elevation in upstream up to 2.7 meter and then its downstream there is no changed of river bed. In station of Paikgacha [Fig. 4], the profile plot is remained in same shape as kobadak downstream reach. In the river reach of Sibsa, there is fluctuation of river bed which indicates that the sediment load is in live load condition as it is a tidal river. Near the station of Paikgacha, deposition depth is 7.5 meter which is overestimation simulated by the Model and gradually decreases it deposition depth in downstream.

\section{Conclusions}

In this study, sediment modeling has been carried out to analyze morphological condition of the Kobadak River

1) The Kobadak River is Small River. The bank of this river is stable over the long years and suspended load and bed load are considered by the yang transport equation. So, modeling river bed and suspended load give satisfactory results.

2) Cross section at Paikgacha which is located in the confluence, increases it's deposition up to end of month June, 2016. Then, from the month of July, the river bed is eroded and the erosion depth is about 2 meter. The river bed of cross section at RMKBD 13 is deposited by amount of 2 meter depth at the month of February but then it has seen erosion by amount of 1 meter up to the time first July. At the end of December, 2016 the river bed is deposited by 1 meter and reached in 2 meter as same as February.

3) The Kobadak upstream reach is eroded in its downstream end by amount of 0.01 to 2 meter and in some locations deposited by amount to 0.01 to 0.5 meter. The Kobadak downstream, Paikgacha and Sibsa reach is deposited abruptly in its upstream location by amount of 2, 2.5 and 7.5 meter respectively. So, the area near confluence is in critical conditions and frequent dredging is required to maintain navigation and prevent water logging problem..

\section{References}

[1] Matsuda I (2004) River Morphology And Channel Processes. Encyclopedia of Life Support Systems (EOLSS)

[2] Rahman A (2002) Hydraulic Model Study of Bed Level Changes of Alluvial River. Department of Water Resource Engineering, Bangladesh University of Engineering and Technology

[3] Bhattacharya B, Price RK, Solomatine DP (2005) Datadriven modelling in the context of sediment transport. Physics and Chemistry of the Earth. https://doi.org/10.1016/j.pce.2004.12.001

\section{Volume 10 Issue 4, April 2021


[4] Larsen EW, Greco SE (2002) Modeling channel management impacts on river migration: A case study of Woodson Bridge State Recreation Area, Sacramento River, California, USA. Environmental Management. https://doi.org/10.1007/s00267-002-2663-1

[5] Bureau of Reclamation, Technical Service Center, Denver, Colorado (2011) Calibration of Numerical Models for the Simulation of Sediment Transport, River Migration, and Vegetation Growth on the Sacramento River, California. U.S. Department of the Interior Bureau of Reclamation

[6] US Army Corps of Engineers (2010) HEC-RAS River Analysis System, User's Manual. HEC-RAS River Analysis System, User's Manual, Version 4.1

[7] Ahmed $\mathrm{T}$ (2016) Kopotakkho River. OFFROAD BANGLADESH

[8] Wilson CA, Goodbred SL (2015) Construction and maintenance of the Ganges-Brahmaputra-Meghna delta: Linking process, morphology, and stratigraphy. Annual Review of Marine Science.https://doi.org/10.1146/annurev-marine010213-135032

[9] Haghiabi AH, Zaredehdasht E (2012) Evaluation of HEC-RAS ability in erosion and sediment transport forecasting. World Applied Sciences Journal

\section{Author Profile}

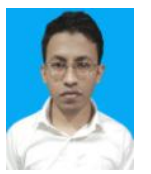

Akramul Haque received the B.Sc. in Water Resources Engineering from Bangladesh University of Engineering \& Technology in 2019. He is pursuing M.Sc. in the same department and working as a Research Assistant at Institute of Water \& Flood Mangement, BUET, Dhaka, Bangladesh. 